Article

\title{
Multi-Segmental Motion in Foot during Counter-Movement Jump with Toe Manipulation
}

\author{
Liangliang Xiang ${ }^{1,2, \dagger}$, Qichang Mei ${ }^{1,2,3, \dagger}$, Datao Xu ${ }^{1}$, Justin Fernandez ${ }^{2,3,4}$ and \\ Yaodong Gu $1,2,3, *$ (D) \\ 1 Faculty of Sports Science, Ningbo University, Ningbo 315211, China; xiangliangliang@21cn.com (L.X.); \\ meiqichangnb@163.com (Q.M.); andywutong@foxmail.com (D.T.) \\ 2 Research Academy of Grand Health, Ningbo University, Ningbo 315211, China; davidjiangci@gmail.com \\ 3 Auckland Bioengineering Institute, University of Auckland, Auckland 1010, New Zealand \\ 4 Department of Engineering Science, University of Auckland, Auckland 1010, New Zealand \\ * Correspondence: guyaodong@hotmail.com; Tel.: +86-574-87609369 \\ + Equally contributed first author.
}

Received: 6 February 2020; Accepted: 6 March 2020; Published: 10 March 2020

check for updates

\begin{abstract}
Human toes are crucial for vertical jumping performance. The purpose of this study is to investigate the acute effect of hallux abduction manipulation on foot inter-segment kinematic alterations and plantar loading redistribution during the countermovement jump (CMJ). Thirteen participants were recruited to join in this experiment, for the collection of the foot inter-segment kinematics and plantar pressure data. During the take-off phase, the contact area presented a significant increase while the pressure-time integral decreased in the second metatarsal (M2), whilst the third metatarsal (M3) and fourth metatarsal (M4) decreased significantly in pressure-time integral with Toe-Manipulation (TM). During the landing phase, maximum force and peak pressure were smaller in the big toe (BT) after hallux abduction manipulation. HXFFA (hallux-forefoot angle) showed a greater pronation after manipulation in the frontal plane $(0 \%-26 \%$ and $50 \%-100 \%)$ with $p=0.002$ and $p<0.001$. In the transverse plane, the smaller adductions were found during $62 \%-82 \%$ in take-off and $62 \%-91 \%$ in landing $(p=0.003$ and $p<0.001)$. There was a redistributed plantar loading during the landing phase from the medial to lateral forefoot. However, a reduced hallux range of motion in the TM session was exhibited, compared to Non-Toe-Manipulation (NTM).
\end{abstract}

Keywords: hallux abduction manipulation; countermovement jump (CMJ); plantar pressure; multi-segment foot kinematics; statistical parametric mapping (SPM)

\section{Introduction}

Barefoot and shod running has received increased attention in recent years, and habitually, barefoot population presented more toe separation [1]. Kadambande et al. [2] found that long-term ill-fitted shoes wearing under weight-bearing conditions restricted natural foot growth and the normal straight alignment. Research findings have indicated that morphological differences in the foot could cause many foot malfunctions, disorders, and deformities, and limited-foot space may cause restricted biomechanical performances in the human foot [3-6].

The human foot is the interface between the body and the ground. Humans locomoted barefoot or with minimalist shoes before the modern shoe was introduced [7]. Recently, the comparisons of shod and barefoot running have led to suggestions that modern running shoes may impair leg and foot-spring function, decrease foot stiffness during locomotion by reducing the contributions from the leg and foot musculature [8]. Studies have proven that running under non-restrictive conditions, such as barefoot or minimal shoes, could increase the strength of intrinsic and extrinsic muscles in feet and 
produce more tactile contact forces [8-11]. Further, the forefoot strike pattern in the barefoot condition showed a stronger longitudinal arch and intrinsic foot muscle, thus functionally improving the mass-spring mechanics of running by storing and releasing elastic energy during locomotion $[8,12,13]$. A recent study has shown that passive hallux adduction, such as wearing narrow-toed shoes, may have a passive tension on the abductor hallucis muscles, decreasing lateral plantar artery blood flow [14]. However, Kelly et al. [15] found participants with running shoes showed increased peak and total stance muscle activation of the intrinsic foot muscles.

The previous studies have proven a converse effect of gait biomechanical performances in the lower limb from either acute or longitudinal hallux-related manipulation [6,16-18]. A 12-week minimal footwear intervention redistributed plantar pressure during gait [6]. Acute toe manipulation increased the inter-segmental flexibility in the foot and laterally redistributed foot loading [18]. Also, an unstable structure under the hallux region may affect the gait and biomechanical performance and increase metatarsophalangeal joint flexibility through the stimulation of the toe gripping function [17].

Vertical jumping is a fundamental movement skill in human beings, which involves the coordination of multi-joint movement [19]. Khuu et al. [20] found that biomechanical assessment during the vertical jump could be used in athletic performance and injury prevention. Vertical jump performance based on morphology-related foot function and the importance of well-functioned toes was recognized while performing a basic jumping task. The contribution of the forefoot and toes has been evaluated while performing the vertical jump, with kinematics, kinetics, and spatiotemporal parameters being analyzed [4]. The toes functioned primarily in a prehensile and ambulatory way, in which the support-based area in the take-off and landing phase of locomotion was enlarged through the gripping action of five separated toes $[5,16]$. A larger plantar loading centralized in the forefoot regions during take-off and landing phases may contribute to the high risk of metatarsal injuries [4].

For habitually barefoot populations, peak pressure and pressure-time integral increased in the big toe and mid-foot regions during the take-off phase and in the big toe and hindfoot regions during landing, comparing to habitually shod populations. Further, habitually barefoot males presented a decreased plantarflexion in the ankle joint as well as external rotation [4]. The morphological differences from hallux abduction manipulation exist mainly in the forefoot and toe regions, which separated the hallux and the second toe, similarly to the concept of minimalist shoes. However, the morphology-based function about the foot inter-segment kinematics alterations and plantar pressure redistribution from the hallux abduction manipulation, while performing a vertical jumping task, has not been investigated yet.

Therefore, the purpose of this study was to investigate the influence of hallux abduction manipulation on foot inter-segment kinematic alterations and the foot plantar pressure redistribution while performing a vertical jump task. It was hypothesized that toe abduction manipulation will reload the plantar pressure during jumping, particularly in the forefoot. The manipulation would also exhibit more flexibility in foot inter-segmental joint angles.

\section{Materials and Methods}

\subsection{Subjects}

The sample size was calculated utilizing the power package (pwr) in RStudio (R-3.6.1) prior to the study (effect size: 0.8 , significance level: 0.05 , power: 0.8 , type: paired $t$-test, alternative: two sided). Thirteen participants (Age: $25.2 \pm 2.2$ years, Height: $170.4 \pm 6.3 \mathrm{~cm}$, Weight: $66.2 \pm 11 \mathrm{~kg}$, BMI: $22.6 \pm$ $2.2 \mathrm{~kg} / \mathrm{m}^{2}$ ), with eight males and five females, were recruited to join in this study. No subjects were on any medication or had an injury or pain to the lower extremity in the past six months. Participants were excluded if presenting any foot deformity or motor system injury that could potentially affect the jump performance. The study procedures were approved by the Ethics Committee from the University, which was in accordance with the Declaration of Helsinki. Written consent forms were 
obtained from all participants, and they were informed of the study objectives, requirements, and experimental design.

\subsection{Experimental Protocol and Procedure}

The countermovement jump (CMJ) has been shown to be the most reliable measure of lower limb muscle strength compared to other jump tests [21]. For CMJ, each subject stood on the force platform with a neutral position and eyes looking forward to perform a maximal jump. Hands were put on the waist during tests as no arm-swing was allowed during the test. Landing in the same position as the take-off was required [19]. All lower extremity plantar pressure data and foot inter-segment angles in this experiment were collected from the left side. Before the data collection, participants were instructed to get familiar with the test environment. A toe separator was placed between the big toe and second toe, and an illustration of the place of hallux abduction manipulation is shown in Figure 1. Five successful trials of the jump task for each subject were recorded without and with the hallux abduction manipulation (Non-Toe-Manipulation, NTM vs. Toe-Manipulation, TM), separately. The NTM session was conducted first as the baseline control. The TM session was the intervention. A 10 min break between the NTM and TM sessions were maintained, and 1 min interval between trials.

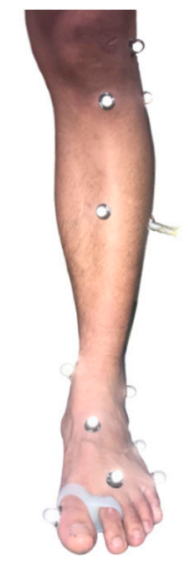

Figure 1. Illustration of hallux abduction manipulation between the hallux and other toes.

A Footscan ${ }^{\circledR}$ pressure plate (Rsscan International, Olen, Belgium, $2096 \times 472 \times 18 \mathrm{~mm}$ ) was fixed in the center of the biomechanics laboratory, with the same surrounding dimensions, to record the dynamic plantar loading patterns with the frequency of $350 \mathrm{~Hz}$. The motion of the lower extremity joints was captured by an eight-infrared camera motion capture system (Vicon Motion System Ltd., Oxford, UK) using the Oxford foot model with 30 reflective markers (diameter: $9 \mathrm{~mm}$ ) and the frequency at $200 \mathrm{~Hz}$ [22]. An AMTI force platform (Advanced Mechanical Technology Inc., Watertown, MA, USA), with frequency at $1000 \mathrm{~Hz}$, was embedded in the center of the eight infrared cameras and utilized to decide take-off and landing subphases during vertical jump tasks. The force platform was zero-leveled before testing each participant. The threshold of the toe-off and contact force platform was defined as the threshold of vertical GRF at $20 \mathrm{~N}$.

For the plantar pressure collection, before each test session, body weight and foot size of each participant were inserted into the Footscan 7 gait 2nd generation software, and one static standing trial was collected to calibrate the Footscan ${ }^{\circledR}$ plate system. For foot inter-segment joints data, marker trajectories and force platform data were recorded synchronously using the Vicon Nexus 1.8.5 software. Static standing trials were conducted for static calibration with the subjects in an anatomically neutral position before performing dynamic $\mathrm{CMJ}$ trials.

\subsection{Data Collection and Statistical Analysis}

$\mathrm{CMJ}$ were classified into the take-off and landing phases for data analysis. The plantar pressure parameter, in this experiment, was measured before and after the hallux abduction manipulation 
intervention sessions (Non-Toe-Manipulation, NTM vs. Toe-Manipulation, TM) to evaluate the change of plantar pressure loading. The collected plantar pressure parameters while performing CMJ include maximum force, force-time integral (impulse), contact area, peak pressure, and pressure-time integral. The plantar surface was divided into ten anatomical regions, including big toe (BT), other toes (OT), first metatarsal (M1), second metatarsal (M2), third metatarsal (M3), fourth metatarsal (M4), fifth metatarsal (M5), midfoot (MF), medial hindfoot (MH), and lateral hindfoot (LH).

As a commonly used multi-segment foot model, the Oxford foot model separated the foot and lower leg as different segments, including the tibia, hindfoot, forefoot, and hallux [18]. The kinematic data included the inter-segment angles of the forefoot relative to the hindfoot (FFHFA), forefoot relative to the tibia (FFTBA) in the sagittal, frontal and transverse planes and hallux relative to the forefoot (HXFFA) in the sagittal and frontal plane, with collection of take-off and landing phases [22].

Paired student $t$-test was utilized in GraphPad Prism ${ }^{\circledR}$ version 8.0.2 (San Diego, CA, USA), for the analysis of plantar pressure distribution. Prior to the $t$-test, the Shapiro-Wilk normality test was conducted, and if it failed, the Wilcoxon matched-pairs signed-rank test was used for the non-parametric test. Mean difference (confidence intervals (95\% CI)) and effect sizes (ES) using Cohen's $\mathrm{d}$ were calculated, and with the three classes benchmarks that small $(0.2<\mathrm{ES}<0.5)$, medium $(0.5<\mathrm{ES}$ $<0.8)$, and large $(E S \geq 0.8)[23,24]$. For the time-series kinematics data, normality was checked prior to statistical analysis in the statistical parametric mapping 1D (spm1d) package. To compare joint kinematics statistical significance, the open-source spm1d code was utilized for the statistical analysis in MATLAB R2019a (The MathWorks Inc., Natick, MA, USA) with the paired-sample $t$-test, and the significance threshold was 5\% [25].

\section{Results}

\subsection{Take-Off Phase}

\subsubsection{Plantar Pressure Distribution}

The plantar pressure data, including maximum force, peak pressure, contact area, force-time integral (impulse), and pressure-time integral was distributed in the BT, OT, M1, M2, M3, M4, M5, MF, $\mathrm{MH}$, and LH regions. Table 1 presents the comparison of plantar pressure during the take-off phase.

The force-time integral (Impulse) and pressure-time integral were smaller after manipulation in the BT ( $p=0.027, p=0.012)$ and M1 $(p=0.009, p=0.025)$ for hallux abduction manipulation. The contact area $(p=0.010)$ illustrated the greater value and pressure-time integral $(p=0.019)$ smaller value in the M2 after hallux abduction manipulation, whilst M3 and M4 were smaller in the pressure-time integral $(p=0.039, p=0.026)$. For the MF, greater values after manipulation were exhibited in the maximum force $(p=0.006)$, contact area $(p=0.002)$, impulse $(p=0.005)$, and pressure-time integral $(p=0.023)$, respectively. For the hindfoot, the maximum force $(p=0.027)$ in the MH showed significant change. No significant difference of plantar pressure parameters was observed in the OT, M5, and LH. 
Table 1. The plantar pressure during take-off in Non-Toe-Manipulation (NTM) and Toe-Manipulation (TM) sessions, including mean (SD), mean difference, $95 \%$ confidence intervals and effect sizes (ES) (Cohen's d). * indicates significance with $p<0.05$.

\begin{tabular}{|c|c|c|c|c|c|c|c|c|c|c|}
\hline \multirow[b]{2}{*}{ Regions } & \multicolumn{2}{|c|}{ Maximum Force } & \multicolumn{2}{|c|}{ Peak Pressure } & \multicolumn{2}{|c|}{ Contact Area } & \multicolumn{2}{|c|}{ Impulse } & \multicolumn{2}{|c|}{ Pressure-Time Integral } \\
\hline & $\begin{array}{l}\text { NTM vs. TM } \\
\text { (Unit: N) }\end{array}$ & $\begin{array}{c}\text { Mean } \\
\text { Difference } \\
(95 \% \text { CI), ES }\end{array}$ & $\begin{array}{l}\text { NTM vs. } \\
\text { TM (Unit: } \\
\text { N/cm²) }\end{array}$ & $\begin{array}{c}\text { Mean } \\
\text { Difference } \\
(95 \% \text { CI), ES }\end{array}$ & $\begin{array}{l}\text { NTM vs. } \\
\text { TM (Unit: } \\
\text { cm }^{2} \text { ) }\end{array}$ & $\begin{array}{c}\text { Mean } \\
\text { Difference } \\
(95 \% \text { CI }), \text { ES }\end{array}$ & $\begin{array}{l}\text { NTM vs. } \\
\text { TM (Unit: } \\
\text { N.s) }\end{array}$ & $\begin{array}{c}\text { Mean } \\
\text { Difference } \\
(95 \% \text { CI }), \text { ES }\end{array}$ & $\begin{array}{l}\text { NTM vs. } \\
\text { TM (Unit: } \\
\mathrm{N} \cdot \mathrm{s} / \mathrm{cm}^{2} \text { ) }\end{array}$ & $\begin{array}{c}\text { Mean } \\
\text { Difference } \\
(95 \% \mathrm{CI}), \mathrm{ES}\end{array}$ \\
\hline $\mathrm{BT}$ & $\begin{array}{l}160.1(75.4), \\
151.6(76.3)\end{array}$ & $\begin{array}{c}8.6(-17.8 \text { to } \\
34.9)\end{array}$ & $\begin{array}{c}9.7(4.5), 9.0 \\
(4.2)\end{array}$ & $\begin{array}{c}0.7(-0.7 \text { to } \\
2.2)\end{array}$ & $\begin{array}{l}15.9(1.8), \\
16.4(3.2)\end{array}$ & $\begin{array}{c}-0.5(-1.7 \text { to } \\
0.7)\end{array}$ & $\begin{array}{l}32.6(21.6) \\
22.6(11.5)\end{array}$ & $\begin{array}{l}8.1(-0.3 \text { to } \\
16.5) 0.59 *\end{array}$ & $\begin{array}{c}2.0(1.3), 1.3 \\
(0.7)\end{array}$ & $\begin{array}{c}0.6(0 \text { to } 1.2) \\
0.59 *\end{array}$ \\
\hline OT & $\begin{array}{c}111.9(50.4), \\
93.8(39.3)\end{array}$ & $\begin{array}{c}18.1(-5.1 \text { to } \\
41.4)\end{array}$ & $\begin{array}{c}4.7(1.6), 4.2 \\
(1.3)\end{array}$ & $\begin{array}{c}0.5(-0.2 \text { to } \\
1.2)\end{array}$ & $\begin{array}{l}22.7(5.0), \\
21.7(4.9)\end{array}$ & $\begin{array}{c}0.9(-2.4 \text { to } \\
4.3)\end{array}$ & $\begin{array}{l}15.1(9.8), \\
11.6(6.2)\end{array}$ & $\begin{array}{c}3.5(-0.3 \text { to } \\
7.4)\end{array}$ & $\begin{array}{c}0.6(0.4), 0.5 \\
(0.3)\end{array}$ & $\begin{array}{c}0.1(-0.1 \text { to } \\
0.3)\end{array}$ \\
\hline M1 & $\begin{array}{l}241.3(123.0), \\
224.1(108.0)\end{array}$ & $\begin{array}{c}17.2(-14.2 \text { to } \\
48.5)\end{array}$ & $\begin{array}{l}11.7(4.8), \\
11.2(3.4)\end{array}$ & $\begin{array}{c}0.5(-1.3 \text { to } \\
2.3)\end{array}$ & $\begin{array}{l}19.4(3.5), \\
18.8(4.0)\end{array}$ & $\begin{array}{c}0.7(-0.7 \text { to } \\
2.0)\end{array}$ & $\begin{array}{l}69.5(33.9) \\
52.9(24.9)\end{array}$ & $\begin{array}{l}16.6(4.8 \text { to } \\
28.5) 0.66 \text { * }\end{array}$ & $\begin{array}{c}3.4(1.3), 2.7 \\
(0.9)\end{array}$ & $\begin{array}{l}0.7 \text { (0.1 to } \\
1.3) \mathbf{0 . 5 5} \text { * }\end{array}$ \\
\hline M2 & $\begin{array}{l}153.1(37.4) \\
161.2(33.1)\end{array}$ & $\begin{array}{c}-8.1(-16.6 \text { to } \\
0.3)\end{array}$ & $\begin{array}{l}14.4(2.9), \\
14.1(2.3)\end{array}$ & $\begin{array}{c}0.3(-0.7 \text { to } \\
1.2)\end{array}$ & $\begin{array}{l}10.3(1.4), \\
11.1(1.9)\end{array}$ & $\begin{array}{c}-0.9(-1.5 \text { to } \\
-0.2) 0.64 *\end{array}$ & $\begin{array}{l}69.9(31.5) \\
63.1(30.0)\end{array}$ & $\begin{array}{c}6.7(-3.1 \text { to } \\
16.6)\end{array}$ & $\begin{array}{c}6.5(2.6), 5.5 \\
(2.6)\end{array}$ & $\begin{array}{l}1.0(0.2 \text { to } \\
1.9) 0.57 \text { * }\end{array}$ \\
\hline M3 & $\begin{array}{l}121.9(25.1) \\
126.4(42.7)\end{array}$ & $\begin{array}{c}-4.5(-19.1 \text { to } \\
10)\end{array}$ & $\begin{array}{l}14.2(3.6), \\
13.6(4.1)\end{array}$ & $\begin{array}{c}0.6(-0.7 \text { to } \\
2.0)\end{array}$ & $\begin{array}{c}8.4(1.1), 8.9 \\
(0.8)\end{array}$ & $\begin{array}{c}-0.5(-1.1 \text { to } \\
0.1)\end{array}$ & $\begin{array}{l}70.3(25.3) \\
62.9(22.2)\end{array}$ & $\begin{array}{c}4(-10.2 \text { to } \\
18.2)\end{array}$ & $\begin{array}{c}8.1(2.6), 6.8 \\
(2.5)\end{array}$ & $\begin{array}{l}1.3(0.1 \text { to } \\
2.4) 0.50 \text { * }\end{array}$ \\
\hline M4 & $\begin{array}{l}75.5(26.3) \\
72.8(18.9)\end{array}$ & $\begin{array}{c}2.7(-8.9 \text { to } \\
14.3)\end{array}$ & $\begin{array}{c}9.3(2.5), 8.5 \\
(1.7)\end{array}$ & $\begin{array}{c}0.8(-0.3 \text { to } \\
2.0)\end{array}$ & $\begin{array}{c}7.8(1.3), 8.3 \\
(1.1)\end{array}$ & $\begin{array}{c}-0.5(-1.0 \text { to } \\
0.0)\end{array}$ & $\begin{array}{l}42.3(9.3) \\
36.5(11.1)\end{array}$ & $\begin{array}{c}5.8(-1.0 \text { to } \\
12.6)\end{array}$ & $\begin{array}{c}5.4(1.6), 4.4 \\
(1.7)\end{array}$ & $\begin{array}{l}1.0(0.1 \text { to } \\
1.9) 0.54 \text { * }\end{array}$ \\
\hline M5 & $\begin{array}{l}54.3(18.3) \\
45.8(16.8)\end{array}$ & $\begin{array}{c}8.6(-3.1 \text { to } \\
20.2)\end{array}$ & $\begin{array}{c}4.3(1.4), 3.7 \\
(1.2)\end{array}$ & $\begin{array}{c}0.6(-0.2 \text { to } \\
1.5)\end{array}$ & $\begin{array}{l}12.2(1.3), \\
12.0(1.4)\end{array}$ & $\begin{array}{c}0.2(-0.7 \text { to } \\
1.1)\end{array}$ & $\begin{array}{l}27.9(15.6) \\
21.7(13.5)\end{array}$ & $\begin{array}{c}6.2(-1.6 \text { to } \\
14.1)\end{array}$ & $\begin{array}{c}2.2(1.2), 1.8 \\
(1.2)\end{array}$ & $\begin{array}{c}0.4(-0.2 \text { to } \\
1.0)\end{array}$ \\
\hline MF & $\begin{array}{c}108.5(41.9) \\
80.6(34.5)\end{array}$ & $\begin{array}{l}27.9(9.1 \text { to } \\
46.8) 0.69 \text { * }\end{array}$ & $\begin{array}{c}2.8(0.9), 2.3 \\
(0.8)\end{array}$ & $\begin{array}{c}0.5 \text { (0.0 to } \\
1.0)\end{array}$ & $\begin{array}{l}37.0(5.9) \\
32.6(8.4)\end{array}$ & $\begin{array}{l}4.4(1.8 \text { to } \\
7.0) 0.79 *\end{array}$ & $\begin{array}{l}68.0(35.7) \\
44.2(26.1)\end{array}$ & $\begin{array}{l}23.7(8.3 \text { to } \\
39.2) 0.72 \text { * }\end{array}$ & $\begin{array}{c}1.7(0.8), 1.3 \\
(0.6)\end{array}$ & $\begin{array}{l}0.5 \text { (0.1 to } \\
0.9) 0.55 \text { * }\end{array}$ \\
\hline $\mathrm{MH}$ & $\begin{array}{l}229.8(69.1) \\
267.1(92.0)\end{array}$ & $\begin{array}{c}-37.3(-69.8 \text { to } \\
-4.8) 0.54 *\end{array}$ & $\begin{array}{l}11.2(2.5), \\
12.6(3.0)\end{array}$ & $\begin{array}{c}-1.3(-2.7 \text { to } \\
0.0)\end{array}$ & $\begin{array}{l}19.6(2.3), \\
20.1(2.7)\end{array}$ & $\begin{array}{c}-0.5(-1.1 \text { to } \\
0.1)\end{array}$ & $\begin{array}{l}185.4(80.1) \\
163.5(52.9)\end{array}$ & $\begin{array}{c}21.9(-8.9 \text { to } \\
52.8)\end{array}$ & $\begin{array}{c}9.1(3.6), 7.7 \\
(1.8)\end{array}$ & $\begin{array}{c}1.3(-0.2 \text { to } \\
2.8)\end{array}$ \\
\hline LH & $\begin{array}{l}231.3(73.5) \\
213.5(44.3)\end{array}$ & $\begin{array}{c}17.9(-17.4 \text { to } \\
53.1)\end{array}$ & $\begin{array}{l}12.8(3.7), \\
11.4(2.1)\end{array}$ & $\begin{array}{c}1.4(-0.4 \text { to } \\
3.2)\end{array}$ & $\begin{array}{l}17.4(2.0), \\
18.1(1.2)\end{array}$ & $\begin{array}{c}-0.6(-1.1 \text { to } \\
0)\end{array}$ & $\begin{array}{l}171.3(80.4) \\
146.5(44.2)\end{array}$ & $\begin{array}{l}24.7(-13.4 \\
\text { to } 62.9)\end{array}$ & $\begin{array}{c}9.6(4.6), 7.9 \\
(2.3)\end{array}$ & $\begin{array}{c}1.8(-0.3 \text { to } \\
3.9)\end{array}$ \\
\hline
\end{tabular}




\subsubsection{Foot Inter-Segment Kinematics}

Figure 2 exhibited the foot inter-segment angle comparisons during take-off under NTM and TM conditions. SPM revealed that HXFFA depicted a significantly greater dorsiflexion angle after manipulation in the sagittal plane (10\%-55\%) with $p<0.001$. Ranges of $76 \%-88 \%$ and $94 \%-100 \%$ showed greater pronation after manipulation in the frontal plane $(p=0.014$ and $p=0.032)$. For FFHFA, the frontal plane exhibited a smaller supination with $p=0.050(0 \%-1 \%)$. In the frontal plane of FFTBA, the supination/pronation was smaller after manipulation during the $70 \%-100 \%$ phase of take-off $(p<0.001)$. In the transverse plane, a smaller adduction during $62 \%-82 \%$ was found $(p=0.003)$.
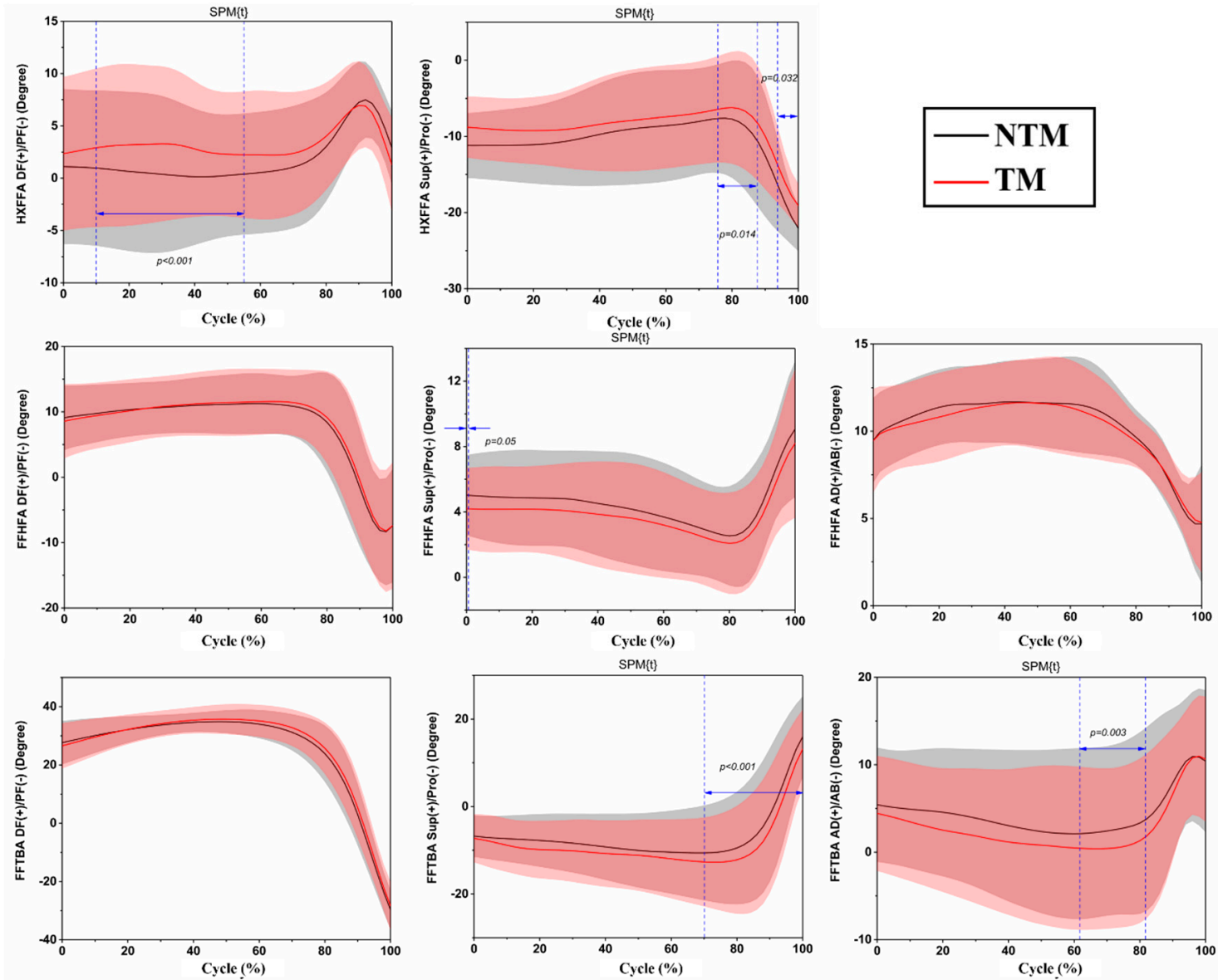

Figure 2. The foot inter-segment angle differences during take-off in Non-Toe-Manipulation (NTM) and Toe-Manipulation (TM) sessions. Blue lines highlighted areas indicate significant differences according to spm1d with $p<0.05$. Abbreviations: DF: dorsiflexion, PF: plantarflexion, Sup: supination, Pro: pronation, AD: adduction, AB: abduction, Inv: inversion, Ev: eversion, Int.: internal rotation, Ext.: external rotation.

\subsection{Landing Phase}

\subsubsection{Plantar Pressure Distribution}

The plantar pressure distribution of landing during CMJ is presented in Table 2. In the BT, the smaller values after hallux abduction manipulation were shown in maximum force $(p=0.034)$ and peak pressure $(p=0.033)$, respectively, whereas no significant change was exhibited in the OT. For M1-M5 regions, no significant difference was observed in the M1, M3, M4, and M5 in the manipulation session, and only maximum force $(p=0.045)$, contact area $(p=0.010)$, impulse $(p=0.013)$, and pressure-time integral $(p=0.027)$ in the M2 were significantly greater after manipulation. It was observed that midfoot and hindfoot reflected no significant change with manipulation in toes. 
Table 2. The plantar pressure during landing in Non-Toe-Manipulation (NTM) and Toe-Manipulation (TM) sessions, including mean (SD), mean difference, $95 \%$ confidence intervals and effect sizes (ES) (Cohen's d). * indicates significance with $p<0.05$.

\begin{tabular}{|c|c|c|c|c|c|c|c|c|c|c|}
\hline \multirow[b]{2}{*}{ Regions } & \multicolumn{2}{|c|}{ Maximum Force } & \multicolumn{2}{|c|}{ Peak Pressure } & \multicolumn{2}{|c|}{ Contact Area } & \multicolumn{2}{|c|}{ Impulse } & \multicolumn{2}{|c|}{ Pressure-Time Integral } \\
\hline & $\begin{array}{l}\text { NTM vs. TM } \\
\text { (Unit: N) }\end{array}$ & $\begin{array}{c}\text { Mean } \\
\text { Difference } \\
(95 \% \text { CI }), \text { ES }\end{array}$ & $\begin{array}{l}\text { NTM vs. } \\
\text { TM (Unit: } \\
\text { N/cm²) }\end{array}$ & $\begin{array}{c}\text { Mean } \\
\text { Difference } \\
(95 \% \text { CI }), \text { ES }\end{array}$ & $\begin{array}{l}\text { NTM vs. } \\
\text { TM (Unit: } \\
\text { cm }^{2} \text { ) }\end{array}$ & $\begin{array}{c}\text { Mean } \\
\text { Difference } \\
(95 \% \text { CI }), \text { ES }\end{array}$ & $\begin{array}{l}\text { NTM vs. } \\
\text { TM (Unit: } \\
\text { N·s) }\end{array}$ & $\begin{array}{c}\text { Mean } \\
\text { Difference } \\
(95 \% \text { CI }), \text { ES }\end{array}$ & $\begin{array}{l}\text { NTM vs. } \\
\text { TM (Unit: } \\
\text { N.s/cm²) }\end{array}$ & $\begin{array}{c}\text { Mean } \\
\text { Difference } \\
(95 \% \text { CI), ES }\end{array}$ \\
\hline BT & $\begin{array}{l}103.4(55.3) \\
74.3(36.3)\end{array}$ & $\begin{array}{l}29.1(2.5 \text { to } \\
55.7) 0.51 \text { * }\end{array}$ & $\begin{array}{c}6.2(2.9), 4.7 \\
(1.5)\end{array}$ & $\begin{array}{l}1.5 \text { (0.1 to } \\
2.8) 0.51 \text { * }\end{array}$ & $\begin{array}{l}15.9(3.0), \\
14.8(3.4)\end{array}$ & $\begin{array}{c}1.0(-0.8 \text { to } \\
2.9)\end{array}$ & $\begin{array}{l}29.8(40.0) \\
26.6(24.8)\end{array}$ & $\begin{array}{c}-0.8(-8.6 \text { to } \\
7.1)\end{array}$ & $\begin{array}{c}1.7(2.1), 1.6 \\
(1.3)\end{array}$ & $\begin{array}{c}0.1(-0.7 \text { to } \\
0.8)\end{array}$ \\
\hline OT & $\begin{array}{l}38.3(22.6), \\
45.0(36.1)\end{array}$ & $\begin{array}{c}-0.7(-9.4 \text { to } \\
8.1)\end{array}$ & $\begin{array}{c}1.6(0.9), 2.0 \\
(1.4)\end{array}$ & $\begin{array}{c}-0.4(-1.0 \text { to } \\
0.2)\end{array}$ & $\begin{array}{l}21.6(4.9), \\
20.3(5.1)\end{array}$ & $\begin{array}{c}0.6(-1.8 \text { to } \\
3.0)\end{array}$ & $\begin{array}{l}10.3(12.9), \\
19.1(26.2)\end{array}$ & $\begin{array}{c}-3.2(-8.0 \text { to } \\
1.6)\end{array}$ & $\begin{array}{c}0.4(0.5), 0.8 \\
(1.1)\end{array}$ & $\begin{array}{c}-0.2(-0.4 \text { to } \\
0.1)\end{array}$ \\
\hline M1 & $\begin{array}{l}161.5(62.2) \\
155.3(51.5)\end{array}$ & $\begin{array}{c}6.2(-25.7 \text { to } \\
38.2)\end{array}$ & $\begin{array}{c}8.1(2.7), 7.9 \\
(2.5)\end{array}$ & $\begin{array}{c}0.1(-1.2 \text { to } \\
1.5)\end{array}$ & $\begin{array}{l}19.1(3.0), \\
19.0(2.5)\end{array}$ & $\begin{array}{c}0.1(-1.4 \text { to } \\
1.6)\end{array}$ & $\begin{array}{l}42.7(33.2), \\
61.9(44.4)\end{array}$ & $\begin{array}{c}-19.2(-45.5 \text { to } \\
7.0)\end{array}$ & $\begin{array}{c}2.0(1.3), 3.0 \\
(2.0)\end{array}$ & $\begin{array}{c}-1.0(-2.1 \text { to } \\
0.1)\end{array}$ \\
\hline M2 & $\begin{array}{l}160.7(59.4) \\
192.0(86.1)\end{array}$ & $\begin{array}{c}-31.3(-61.9 \text { to } \\
-0.8) \mathbf{0 . 4 8}\end{array}$ & $\begin{array}{l}15.0(6.2) \\
15.5(6.9)\end{array}$ & $\begin{array}{c}-0.5(-3.1 \text { to } \\
2.0)\end{array}$ & $\begin{array}{l}10.6(1.7) \\
11.9(1.5)\end{array}$ & $\begin{array}{l}-1.3(-2.2 \text { to } \\
-0.4) 0.64\end{array}$ & $\begin{array}{l}58.8 \text { (41.7), } \\
96.8 \text { (75.6) }\end{array}$ & $\begin{array}{c}-38.0(-66.8 \text { to } \\
-9.2) 0.62 *\end{array}$ & $\begin{array}{c}5.4(3.8), 7.7 \\
(5.7)\end{array}$ & $\begin{array}{c}-2.3(-4.4 \text { to } \\
-0.3) 0.54\end{array}$ \\
\hline M3 & $\begin{array}{l}148.7(39.0) \\
153.4(50.0)\end{array}$ & $\begin{array}{c}-4.7(-32.0 \text { to } \\
22.7)\end{array}$ & $\begin{array}{l}15.5(3.7) \\
15.4(4.3)\end{array}$ & $\begin{array}{c}0.1(-2.3 \text { to } \\
2.5)\end{array}$ & $\begin{array}{c}9.3(1.1), 9.6 \\
(1.3)\end{array}$ & $\begin{array}{c}-0.3(-1.1 \text { to } \\
0.5)\end{array}$ & $\begin{array}{l}69.1(51.1) \\
87.3(71.5)\end{array}$ & $\begin{array}{c}-9.3(-31.8 \text { to } \\
13.2)\end{array}$ & $\begin{array}{c}7.3(5.8), 8.3 \\
(5.8)\end{array}$ & $\begin{array}{c}-1.0(-2.6 \text { to } \\
0.7)\end{array}$ \\
\hline M4 & $\begin{array}{c}105.7(28.7) \\
89.3(38.9)\end{array}$ & $\begin{array}{c}16.4(-8.1 \text { to } \\
41.0)\end{array}$ & $\begin{array}{c}11.3(2.6), 9.6 \\
(4.0)\end{array}$ & $\begin{array}{c}1.0(-1.1 \text { to } \\
3.0)\end{array}$ & $\begin{array}{c}9.0(1.2), 9.3 \\
(1.6)\end{array}$ & $\begin{array}{c}-0.3(-1.1 \text { to } \\
0.5)\end{array}$ & $\begin{array}{l}50.9(39.4) \\
47.8(48.0)\end{array}$ & $\begin{array}{c}3.2(-8.5 \text { to } \\
14.9)\end{array}$ & $\begin{array}{c}5.5(4.2), 4.8 \\
(3.9)\end{array}$ & $\begin{array}{c}-0.1(-1.5 \text { to } \\
1.3)\end{array}$ \\
\hline M5 & $\begin{array}{l}89.4(31.8) \\
65.6(39.4)\end{array}$ & $\begin{array}{c}23.8(-2.8 \text { to } \\
50.3)\end{array}$ & $\begin{array}{c}5.9(2.0), 4.6 \\
(2.6)\end{array}$ & $\begin{array}{c}1.4(-0.3 \text { to } \\
3.0)\end{array}$ & $\begin{array}{l}14.5(2.2), \\
14.0(1.8)\end{array}$ & $\begin{array}{c}0.6(-0.7 \text { to } \\
1.9)\end{array}$ & $\begin{array}{l}37.5(33.4) \\
25.7(29.4)\end{array}$ & $\begin{array}{c}8.6(-4.4 \text { to } \\
21.5)\end{array}$ & $\begin{array}{c}2.5(2.2), 1.7 \\
(1.7)\end{array}$ & $\begin{array}{c}0.4(-0.5 \text { to } \\
1.3)\end{array}$ \\
\hline MF & $\begin{array}{l}254.6(135.7) \\
203.4(127.7)\end{array}$ & $\begin{array}{c}51.2(-20.8 \text { to } \\
123.2)\end{array}$ & $\begin{array}{c}6.0(2.6), 4.9 \\
(2.3)\end{array}$ & $\begin{array}{c}1.1(-0.4 \text { to } \\
2.6)\end{array}$ & $\begin{array}{l}39.8(7.9) \\
37.9(7.5)\end{array}$ & $\begin{array}{c}1.9(-1.9 \text { to } \\
5.6)\end{array}$ & $\begin{array}{l}56.4(68.6) \\
69.0(85.1)\end{array}$ & $\begin{array}{c}-4.6(-42.7 \text { to } \\
33.6)\end{array}$ & $\begin{array}{c}1.3(1.7), 1.7 \\
(1.8)\end{array}$ & $\begin{array}{c}-0.3(-1.1 \text { to } \\
0.6)\end{array}$ \\
\hline $\mathrm{MH}$ & $\begin{array}{l}297.9(139.0) \\
295.0(134.3)\end{array}$ & $\begin{array}{c}2.8(-94.8 \text { to } \\
100.4)\end{array}$ & $\begin{array}{l}16.1(6.0) \\
14.7(5.9)\end{array}$ & $\begin{array}{c}1.5(-2.5 \text { to } \\
5.4)\end{array}$ & $\begin{array}{l}17.6(3.5) \\
19.5(3.6)\end{array}$ & $\begin{array}{c}-1.9(-4.6 \text { to } \\
0.8)\end{array}$ & $\begin{array}{c}109.4 \\
(130.2) \\
113.9(85.1)\end{array}$ & $\begin{array}{c}-17.2(-55.7 \text { to } \\
21.4)\end{array}$ & $\begin{array}{c}5.5(5.5), 5.5 \\
(3.9)\end{array}$ & $\begin{array}{c}0.0(-2.0 \text { to } \\
2.1)\end{array}$ \\
\hline $\mathrm{LH}$ & $\begin{array}{l}243.1(112.6) \\
264.2(102.5)\end{array}$ & $\begin{array}{c}-31.6(-97.9 \text { to } \\
34.8)\end{array}$ & $\begin{array}{l}14.4(4.8) \\
14.4(4.4)\end{array}$ & $\begin{array}{c}0.1(-2.1 \text { to } \\
2.2)\end{array}$ & $\begin{array}{l}16.3(4.7), \\
17.7(3.4)\end{array}$ & $\begin{array}{c}-2.4(-4.5 \text { to } \\
-0.3)\end{array}$ & $\begin{array}{c}78.2 \\
(104.7) \\
83.7(65.9)\end{array}$ & $\begin{array}{c}-5.5(-40.4 \text { to } \\
29.3)\end{array}$ & $\begin{array}{c}4.4(5.1), 4.7 \\
(3.8)\end{array}$ & $\begin{array}{c}-1.3(-2.9 \text { to } \\
0.4)\end{array}$ \\
\hline
\end{tabular}




\subsubsection{Foot Inter-Segment Kinematics}

Figure 3 exhibited the foot inter-segment angle comparison during landing under NTM and TM conditions. The greater pronation after manipulation was found in HXFFA with $p=0.002$ and $p<0.001(0 \%-26 \%$ and 50\%-100\%). The range 4\%-6\% showed a smaller supination with $p=0.05$, for FFHFA. Pronation was smaller after manipulation in $64 \%-95 \%$ of the frontal plane of FFTBA $(p<0.001)$. Adduction was smaller with $p<0.001$ in the transverse plane at $62 \%-91 \%$ of landing.
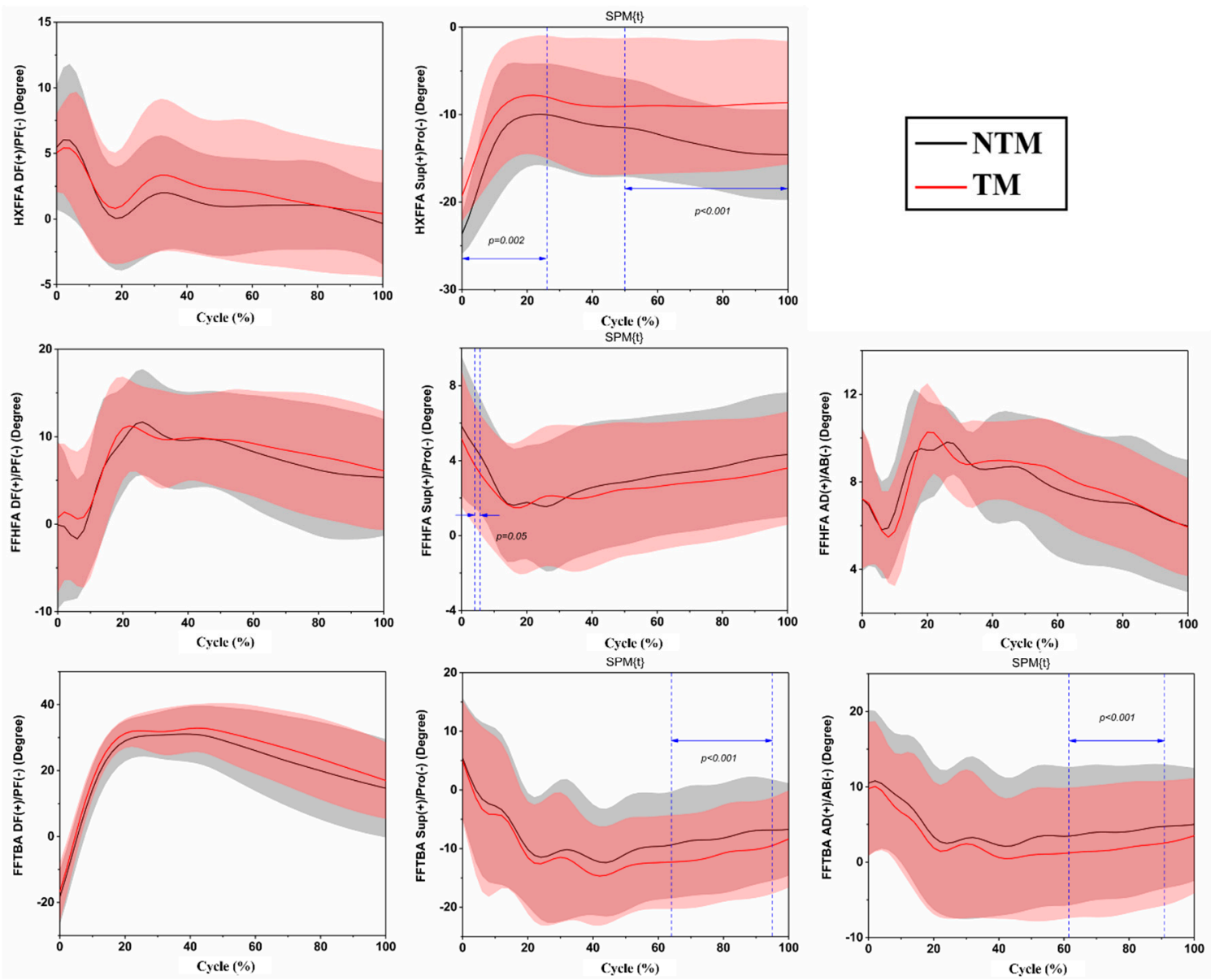

Figure 3. The foot inter-segment angle differences during landing in Non-Toe-Manipulation (NTM) and Toe-Manipulation (TM) sessions. Blue lines highlight areas that indicate significant differences according to spm1d with $p<0.05$. Abbreviations: DF: dorsiflexion, PF: plantarflexion, Sup: supination, Pro: pronation, AD: adduction, AB: abduction, Inv: inversion, Ev: eversion, Int.: internal rotation, Ext.: external rotation.

Figure 4 showed the sagittal HXFFA angle against the frontal HXFFA angle during the take-off and landing phases. The starting and ending coordinates of the take-off phase was $(1.10,-11.19)$ and $(2.93,-22.05)$ for NTM, and $(2.34,-8.79)$ to $(1.30,-19.07)$ for TM. During the landing phase, $(5.05,-19.29)$ to $(0.41,-8.64)$ with hallux abduction manipulation compared to $(5.47,-23.65)$ to $(-0.34$, -14.59). The range of motion (ROM) was $(1.83,10.86)$ in the NTM session and $(1.04,10.28)$ in the TM session during the take-off phase, $(5.81,9.06)$ and $(4.64,10.65)$ in the landing phase. 


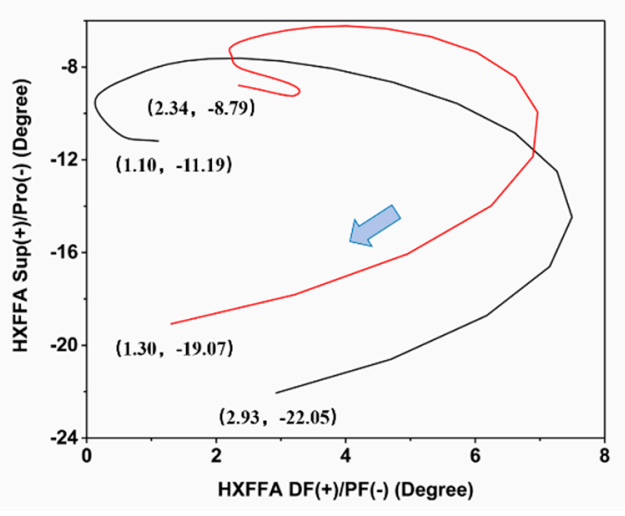

(a)

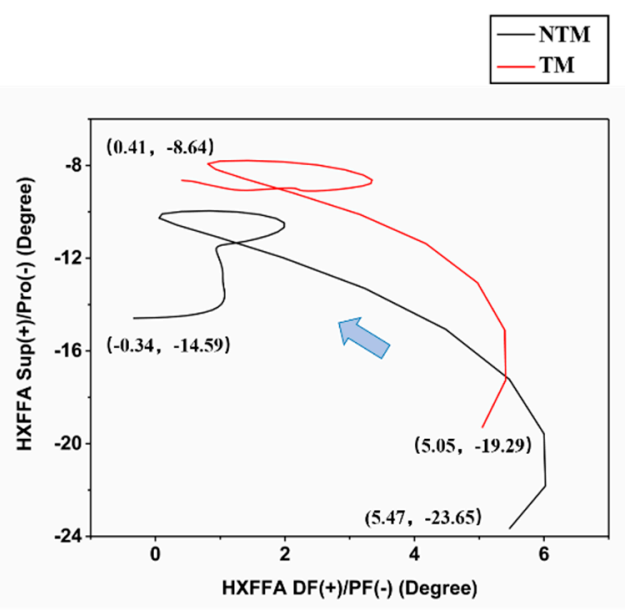

(b)

Figure 4. The sagittal (X-axis) and frontal (Y-axis) HXFFA angles during take-off (a) and landing (b) phases in Non-Toe-Manipulation (NTM) and Toe-Manipulation (TM) sessions. Abbreviations: DF: dorsiflexion, PF: plantarflexion, Sup: supination, Pro: pronation.

\section{Discussion}

In this study, we compared toe abduction manipulation (TM) and non-manipulation (NTM) conditions to explore the foot inter-segment kinematics and plantar loading pattern during CMJ taking-off and landing phases. It was found that manipulation in toes, during the landing phase, could redistribute forefoot loading from the medial to lateral region. Further, the forefoot inter-segment increased flexibility, and the hallux relative to the forefoot (HXFFA) showed a decreased range of motion while comparing to the non-manipulation.

As injuries of the ankle and the knee are frequently observed during jump landings, landing tasks are vital not only for performance but also for the prevention of injury risk [26-28]. For the jump task, larger plantar loading at the forefoot region during take-off and landing phases may increase the risk of metatarsal injuries [4]. Several foot disorders, such as hallux valgus, usually present high plantar pressure in medial forefoot $[29,30]$. Modern footwear has been designed with narrow space, especially in the forefoot [6]. Ill-fitted or constrictive toe-box shoes would disrupt the normal alignment of the first metatarsophalangeal joint and even induce hallux valgus [1]. Furthermore, the above issue may affect toe functionality, such as prehensile and ambulatory ability $[5,16]$.

In this study, the results showed that hallux abduction manipulation could reduce impulse and pressure-time integral in BT and M1 during the take-off phase. The maximum force increased in BT and M1 and decreased in M2 during landing. This is consistent with our previous work that for hallux valgus patients, the forefoot plantar pressure was redistributed centrally from M1 to M2-M4, after three months of minimal-shoes running intervention [6].

Footwear with constrictive forefoot space or insufficient footwear width may limit toes' activities during locomotion, thus affecting the lower limb kinematic performance [31]. Foot symptoms, such as hallux valgus, showed a reduced ROM in the lower extremity joints and weaker propulsive function during the push-off phase of gait [32]. A study reported that patients with hallux valgus presented reduced dorsiflexion range of motion in the first metatarsophalangeal joint [33]. Casey Kerrigan et al. [34] found that ankle dorsiflexion decreased in loading response among barefoot runners. Azevedo et al. [35] found professional dancers exhibited higher forefoot-hindfoot plantarflexion than non-dancers during landing. However, no significant difference exists between non-binding and binding hallux conditions [16].

In this study, the toes abduction manipulation with subtle foot morphology change exhibited great impact in the HXFFA, which is consistent with our previous hypothesis: an increased dorsiflexion range of motion of HXFFA was presented during take-off and landing phases. However, the ROM 
of HXFFA showed a decrease, and the pronation angle showed an increase with hallux abduction manipulation. This is consistent with the understanding that toe manipulation may restrict relative foot joint motion. It should be acknowledged that there was only a ten-minute interval between the two CMJ sessions, and participants might be accustomed to the toe separator manipulation. Another issue on the potential effect from male and female difference was not considered, which shall be the next study objective.

However, there is still one main limitation. No muscle activity (EMG) data was involved in this study. Future studies should investigate the acute effect of TM on foot intrinsic and extrinsic muscle activities to further elaborate the potential effect.

\section{Conclusions}

In summary, this study conducted a perspective investigation into the acute effect of toe manipulation on the foot inter-segment kinematic alterations and plantar pressure distribution during a countermovement jump. A redistributed plantar loading during the landing phase from the medial to lateral forefoot was found. A reduced hallux range of motion in the TM session was exhibited comparing to NTM. Findings from this study indicated that hallux manipulation can provide a forefoot unrestricted condition that could be potentially used for hallux valgus treatment and gait training.

Author Contributions: Conceptualization, L.X., Q.M. and Y.G.; methodology, L.X. and D.X.; software, Q.M.; validation, J.F.; formal analysis, L.X., Q.M. and D.X.; investigation, L.X., Q.M. and D.X.; resources, Y.G.; data curation, Q.M. and D.X.; writing-original draft preparation, L.X. and Q.M.; writing-review and editing, J.F. and Y.G.; visualization, L.X. and D.X.; supervision, J.F. and Y.G.; project administration, Y.G.; funding acquisition, Y.G. All authors have read and agreed to the published version of the manuscript.

Funding: This research was funded by the National Natural Science Foundation of China (81772423), National Key R\&D Program of China (2018YFF0300903), and K.C. Wong Magna Fund in Ningbo University.

Conflicts of Interest: The authors declare no conflict of interest.

\section{References}

1. Shu, Y.; Mei, Q.; Fernandez, J.; Li, Z.; Feng, N.; Gu, Y. Foot Morphological Difference between Habitually Shod and Unshod Runners. PLoS ONE 2015, 10, e0131385. [CrossRef] [PubMed]

2. Kadambande, S.; Khurana, A.; Debnath, U.; Bansal, M.; Hariharan, K. Comparative anthropometric analysis of shod and unshod feet. Foot 2006, 16, 188-191. [CrossRef]

3. Jiang, C. The effect of basketball shoe collar on ankle stability: a systematic review and meta-analysis. Phys. Act. Health 2020, 4, 11-18. [CrossRef]

4. Shu, Y.; Zhang, Y.; Fu, L.; Fekete, G.; Baker, J.S.; Li, J.; Gu, Y. Dynamic loading and kinematics analysis of vertical jump based on different forefoot morphology. SpringerPlus 2016, 5, 1999. [CrossRef]

5. Lambrinudi, C. Use and Abuse of Toes. Postgrad. Med. J. 1932, 8, 459-464. [CrossRef]

6. Xiang, L.; Mei, Q.; Fernandez, J.; Gu, Y. Minimalist shoes running intervention can alter the plantar loading distribution and deformation of hallux valgus: A pilot study. Gait Posture 2018, 65, 65-71. [CrossRef]

7. D'Août, K.; Pataky, T.; De Clercq, D.; Aerts, P. The effects of habitual footwear use: Foot shape and function in native barefoot walkers. Footwear Sci. 2009, 1, 81-94. [CrossRef]

8. Lieberman, D.E.; Venkadesan, M.; Werbel, W.A.; Daoud, A.I.; D'Andrea, S.; Davis, I.S.; Mang'Eni, R.O.; Pitsiladis, Y. Foot strike patterns and collision forces in habitually barefoot versus shod runners. Nature 2010, 463, 531-535. [CrossRef]

9. Goldmann, J.-P.; Potthast, W.; Brüggemann, G.-P. Athletic training with minimal footwear strengthens toe flexor muscles. Footwear Sci. 2013, 5, 19-25. [CrossRef]

10. Davis, I.S.; Rice, H.; Wearing, S.C. Why forefoot striking in minimal shoes might positively change the course of running injuries. J. Sport Health Sci. 2017, 6, 154-161. [CrossRef]

11. Chen, T.L.-W.; Sze, L.K.; Davis, I.S.; Cheung, R.T.H. Effects of training in minimalist shoes on the intrinsic and extrinsic foot muscle volume. Clin. Biomech. 2016, 36, 8-13. [CrossRef]

12. Lieberman, D.E. What We Can Learn About Running from Barefoot Running. Exerc. Sport Sci. Rev. 2012, 40, 63-72. [CrossRef] 
13. Jungers, W.L. Biomechanics: Barefoot running strikes back. Nature 2010, 463, 433-434. [CrossRef]

14. Johnson, A.W.; Dunbar, J.L.; Ridge, S.T.; Bruening, D.; Brewerton, K.; Gifford, J.; Hoopes, D. Passive Hallux Adduction Decreases Lateral Plantar Artery Blood Flow in Low Arch Feet. Med. Sci. Sports Exerc. 2019, 51, 887. [CrossRef]

15. Kelly, L.A.; Lichtwark, G.; Farris, D.J.; Cresswell, A. Shoes alter the spring-like function of the human foot during running. J. R. Soc. Interface 2016, 13, 20160174. [CrossRef] [PubMed]

16. Mei, Q.; Fernandez, J.; Hume, P.; Gu, Y. Investigating biomechanical function of toes through external manipulation integrating analysis. Acta Bioeng. Biomech. 2016, 18, 87-92.

17. Mei, Q.; Gu, Y.; Fernandez, J. A biomechanical assessment of running with hallux unstable shoes of different material stiffness. Acta Bioeng. Biomech. 2019, 21, 121-128.

18. Xiang, L.; Mei, Q.; Fernandez, J.; Gu, Y. A biomechanical assessment of the acute hallux abduction manipulation intervention. Gait Posture 2020, 76, 210-217. [CrossRef] [PubMed]

19. Petrigna, L.; Karsten, B.; Marcolin, G.; Paoli, A.; D'Antona, G.; Palma, A.; Bianco, A. A Review of Countermovement and Squat Jump Testing Methods in the Context of Public Health Examination in Adolescence: Reliability and Feasibility of Current Testing Procedures. Front. Physiol. 2019, 10, 1384. [CrossRef]

20. Khuu, S.; Musalem, L.L.; Beach, T.A.C. Verbal Instructions Acutely Affect Drop Vertical Jump Biomechanics-Implications for Athletic Performance and Injury Risk Assessments. J. Strength Cond. Res. 2015, 29, 2816-2826. [CrossRef]

21. Klavora, P. Vertical-jump Tests: A Critical Review. Strength Cond. J. 2000, 22, 70. [CrossRef]

22. Stebbins, J.; Harrington, M.; Thompson, N.; Zavatsky, A.; Theologis, T. Repeatability of a model for measuring multi-segment foot kinematics in children. Gait Posture 2006, 23, 401-410. [CrossRef] [PubMed]

23. Cohen, J. Statistical Power Analysis for the Behavioral Sciences, 2nd ed.; Lawrence Erlbaum: Hillsdale, NJ, USA, 1988.

24. Dawson, J.; Boller, I.; Doll, H.; Lavis, G.; Sharp, R.; Cooke, P.; Jenkinson, C. Minimally important change was estimated for the Manchester-Oxford Foot Questionnaire after foot/ankle surgery. J. Clin. Epidemiol. 2014, 67, 697-705. [CrossRef] [PubMed]

25. Pataky, T. Generalized n-dimensional biomechanical field analysis using statistical parametric mapping. J. Biomech. 2010, 43, 1976-1982. [CrossRef] [PubMed]

26. Yu, B.; Lin, C.-F.; Garrett, W.E. Lower extremity biomechanics during the landing of a stop-jump task. Clin. Biomech. 2006, 21, 297-305. [CrossRef] [PubMed]

27. Fransz, D.; Huurnink, A.; Kingma, I.; De Boode, V.A.; Heyligers, I.C.; Van Dieën, J. Performance on a Single-Legged Drop-Jump Landing Test Is Related to Increased Risk of Lateral Ankle Sprains Among Male Elite Soccer Players: A 3-Year Prospective Cohort Study. Am. J. Sports Med. 2018, 46, 3454-3462. [CrossRef]

28. Ford, K.R.; Myer, G.D.; Hewett, T.E. Valgus Knee Motion during Landing in High School Female and Male Basketball Players. Med. Sci. Sports Exerc. 2003, 35, 1745-1750. [CrossRef]

29. Martínez-Nova, A.; Rodríguez, R.S.; Pérez-Soriano, P.; Llana-Belloch, S.; Leal-Muro, A.; Pedrera-Zamorano, J.D. Plantar pressures determinants in mild Hallux Valgus. Gait Posture 2010, 32, 425-427. [CrossRef]

30. Wen, J.; Ding, Q.; Yu, Z.; Sun, W.; Wang, Q.; Wei, K. Adaptive changes of foot pressure in hallux valgus patients. Gait Posture 2012, 36, 344-349. [CrossRef]

31. Wallden, M. Toe-tal recall—What on Earth are our toes actually for? J. Bodyw. Mov. Ther. 2016, $20,418-431$. [CrossRef]

32. Scott, G.; Menz, H.B.; Newcombe, L. Age-related differences in foot structure and function. Gait Posture 2007, 26, 68-75. [CrossRef] [PubMed]

33. Nix, S.; Vicenzino, B.; Collins, N.; Smith, M. Characteristics of foot structure and footwear associated with hallux valgus: A systematic review. Osteoarthr. Cartil. 2012, 20, 1059-1074. [CrossRef] [PubMed] 
34. Kerrigan, D.C.; Franz, J.R.; Keenan, G.S.; Dicharry, J.; Della Croce, U.; Wilder, R.P. The Effect of Running Shoes on Lower Extremity Joint Torques. PMER 2009, 1, 1058-1063.

35. Jana, P.; Mukherjee, T.; Khurana, R.; Barooah, N.; Soppina, V.; Mohanty, J.; Kanvah, S. Oxford Foot Model kinematics in landings: A comparison between professional dancers and non-dancers. J. Sci. Med. Sport 2019, 112062.

(C) 2020 by the authors. Licensee MDPI, Basel, Switzerland. This article is an open access article distributed under the terms and conditions of the Creative Commons Attribution (CC BY) license (http://creativecommons.org/licenses/by/4.0/). 